\section{References}

Comty, C. M., Baillod, R. A., Crockett, R., and Shaldon, S. (1966). Proceedings of European Dialysis and Transplant Association, 3, 98.

Crockett, R. E., et al. (1967). Proceedings of European Dialysis and Transplant Association, 4, 17.

Druckker, W., Haagsma-Schouten, W. A. G., Alberts, C., and Spoek, M. G. (1969). Proceedings of European Dialysis and Transplant Association, 6, 99 .

Eschbach, J. W. (1969). Fourth International Congress of Nephrology. Abstracts of General Sessions Symposia, p. 161.

Eschbach, J. W., Cook, J. D., and Finch, C. A. (1970). Clinical Science, 38, 191 .

Fried, W., and Gurney, C. W. (1968). Annals of the New York Academy of Science, 149, 356.

Gordon, A. S., Mirand, E. A., Wenig, J., Katz, R., and Zanjani, E. D. (1968). Annals of the New York Academy of Science, 149, 318.
Killander, A., Lundmark, K. M., and Sjolin, S. (1969). Acta Paediatrica Scandinavicka, 58, 10

Lawson, D. H., Will, G., Boddy, K., and Linton, A. L. (1968). Proceedings of European Dialysis and Transplant Association, 5, 167.

Mirand, E. A., Gordon, A. S., and Wenig, J. (1965). Nature, 206, 270.

Mirand, E. A., Murphy, G. P., Steeves, R. A., Groenewald, J. M., and De Klerk, J. N. (1969). Fournal of Laboratory and Clinical Medicine, 73,121

Parsons, F. M., and Clark, P. B. (1969). Proceedings of European Dialysis and Transplant Association, 6, 217.

Shahidi, N. T., and Diamond, L. N. (1961). New England fournal Medicine, 264, 953.

Shaldon, S. (1966). Postgraduate Medical fournal, 42, 671.

Verroust, P. J., et al. (1967). Proceedings of European Dialysis and Transplant Association, 4, 12

Wright, F. K., Goldsmith, H. J., and Hall, S. M. (1968). Proceedings of European Dialysis and Transplant Association, 5, 179.

\title{
Comparative Double-blind Trial of Cephalexin and Ampicillin in Treatment of Urinary Infections
}

\author{
J. A. DAVIES, J. E. M. STRANGEWAYS, R. G. MITCHELL， L. J. BEILIN， J. G. G. LEDINGHAM, \\ J. M. HOLT
}

British Medical fournal, 1971, 3, 215-217

\section{Summary}

Cephalexin was compared with ampicillin in the treatment of urinary tract infections by a random doubleblind technique. Both drugs were found to be equally effective. In 21 out of 31 patients treated with cephalexin and in 20 out of 31 treated with ampicillin the urine was sterile three weeks after starting therapy. The bacteriological findings at one and eight weeks were also similar in both groups. No serious adverse reactions were attributable to cephalexin, which seemed to be tolerated rather better than ampicillin.

\section{Introduction}

Cephalexin is a semisynthetic cephalosporin which is effectively absorbed from the gastrointestinal tract (Griffith and Black, 1968; Gower and Dash, 1969; Davies, Strangeways, and Holt, 1970). Antibacterial activity has been demonstrated against a wide range of Gram-negative and Gram-positive organisms (Perkins, Carlisle, and Saslaw, 1968). It is excreted unchanged in the urine in high concentration (Meyers, Kaplan, and Weinstein, 1969), and preliminary investigations have suggested that it may be effective in the treatment of urinary tract infections (Leigh, Faiers, and Brumfitt, 1970). This report describes a double-blind trial designed to compare cephalexin with ampicillin in the treatment of urinary tract infections.

\section{Methods}

Sixty-four patients were studied, comprising eight men and 56 non-pregnant women aged 19 to 83 years. Pyelography

\footnotetext{
Departments of Medicine and Bacteriology, United Oxford Hospitals J. A. DAVIES, M.R.C.P., Registrar in Therapeutics

J. E. M. STRANGEWAYS, M.B., B.S., Registrar in Bacteriology

R. G. MITCHELL, D.M., M.R.C.P., Consultant Bacteriologist

L. J. BEILIN, M.D., M.R.C.P., Physician, Clinical Therapeutics Group

J. G. G. LEDINGHAM, D.M., F.R.C.P., Physician, Clinical Therapeutics

Group

J. M. HOLT, M.D., M.R.c.P., Physician, Clinical Therapeutics Group
}

showed abnormalities of the urinary tract in 10 patients. Forty-eight were inpatients, and some were seriously ill due to disorders outside the urinary tract, which resulted in the deaths of four patients during the course of the study. The diagnosis of urinary tract infection was accepted when a similar organism was grown from two consecutive urine samples in a concentration of more than 100,000 organisms per ml. We excluded from the trial patients with a history of penicillin hypersensitivity, patients with indwelling urethral catheters, and patients infected with Pseudomonas aeruginosa or Proteus strains other than Proteus mirabilis, since these organisms are known to be resistant to both cephalexin (Wick, 1967), and ampicillin (Anderson, Kennedy, Plorde, Shulman, and Petersdorf, 1964). Patients were not excluded on the basis of resistance of the infecting organism to the test antibiotics on preliminary sensitivity testing.

Treatment.-Each patient received either cephalexin or ampicillin $500 \mathrm{mg}$ six-hourly for 10 days. Supplies of cephalexin and ampicillin made up by Glaxo Laboratories Ltd. in identical capsules, identified only as drugs $A$ and $B$, were held by the hospital pharmacy. Treatment was allocated at random, from a list stratified to ensure a similar proportion of uncomplicated cases in each group, and the drugs were distributed by the pharmacy in a container unmarked except for directions. The code was broken on completion of the study.

Assessment of Treatment.- Urine was cultured at one, three, and eight weeks after the beginning of the treatment. Patients were seen by one of us (J.A.D.) at the same intervals, and after one week a check was made on the number of capsules remaining, to establish that the prescribed dose was being taken. Those who relapsed were given appropriate alternative therapy and thereafter were excluded from further study.

Assessment of Adverse Reactions.-Spontaneous complaints attributed to the test drugs were recorded, and each patient was then questioned specifically about diarrhoea, flatulence, nausea, vomiting, pruritus, and rashes. The haemoglobin, white blood count, E.S.R., one-stage prothrombin time, serum urea, alkaline phosphatase, aspatate aminotransferase, and lactic dehydrogenase levels were measured before and one week after the start of treatment.

Bacteriology.-Urine specimens were cultured within two hours of voiding with the calibrated loop technique of Guttman 
and Stokes (1963). Organisms were identified by standard methods, and preliminary sensitivities were determined by the agar-gel diffusion method, cephalexin $25 \mu \mathrm{g}$ and ampicillin $25 \mu \mathrm{g}$ discs being used. The minimum inhibitory concentrations (M.I.C.s) for cephalexin and ampicillin were determined by the plate incorporation technique, each doubling-dilution series of plates being inoculated with the multipoint apparatus devised by Watt, Jefferies, and Price (1966). The M.I.C. was determined as the lowest concentration of antibiotic which completely inhibited growth.

\section{Results}

The main details of the 64 patients in the trial are summarized in Table I. The two treatment groups are similarly constituted. The outcome of antimicrobial therapy at one, three, and eight weeks after starting treatment is summarized in Table II. After one week treatment had failed in one of the 31 patients treated with cephalexin and in three of 31 treated with ampicillin. Two others in the ampicillin group developed intolerable diarrhoea, which led to withdrawal of the test drug after less than 48 hours of therapy and to alternative treatment. During the eight-week period of study either the original organism was not eradicated or an organism similar to the original infecting strain reappeared in a total of 10 of the 31 patients in the cephalexin group and 8 of the 31 in the ampicillin group.

TABLE I-Clinical Details of Patients Studied

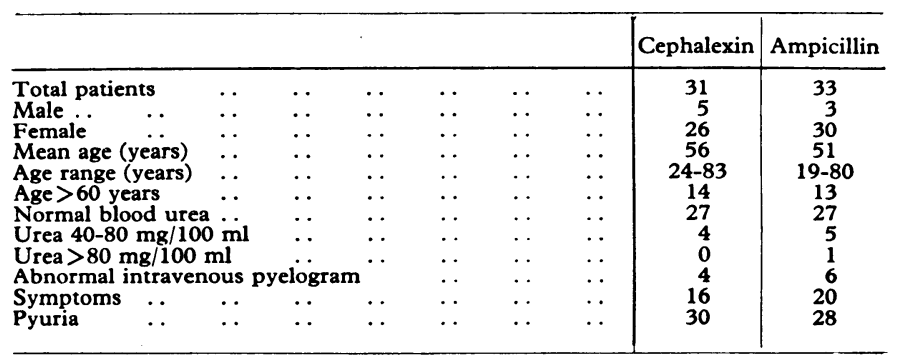

TABLE IV-Adverse Reactions during Treatment

\begin{tabular}{|c|c|c|c|c|c|}
\hline & & \multicolumn{2}{|c|}{$\begin{array}{c}\text { Cephalexin } \\
\text { (31 patients) }\end{array}$} & \multicolumn{2}{|c|}{$\underset{(33 \text { patients })}{\text { Ampicillin }}$} \\
\hline & & Volunteered & Elicited & Volunteered & Elicited \\
\hline $\begin{array}{l}\text { Troublesome diarrhoea } \\
\text { Mild diarrhoea } \\
\text { Flatulence } \\
\text { Rash }\end{array}$ & $\begin{array}{l}\cdots \\
\because \\
\because\end{array}$ & $\begin{array}{l}1 \\
1\end{array}$ & $\begin{array}{l}5 \\
2\end{array}$ & $\begin{array}{l}2 \\
2 \\
2\end{array}$ & 3 \\
\hline
\end{tabular}

Table III shows the outcome of treatment by the third week in relation to the original infecting organism; the distribution of infecting strains was similar in the two groups. Three patients received an antibiotic to which their organism was resistant on preliminary testing. Only one of these patients, treated with ampicillin, who had pyelographic evidence of chronic pyelonephritis, relapsed because of infection with a similar organism to the original infecting strain. The minor differences between the two groups were not statistically significant, and it was concluded that the two drugs were equally effective.

Adverse Reactions. - The incidence and type of adverse reaction to treatment observed are shown in Table IV. The treatment of two patients in the ampicillin group was prematurely halted because of severe diarrhoea. Two others in the ampicillin group developed a rash but this cleared promptly after treatment had finished. None of the side effects attributed to cephalexin led to suspension of treatment, and in only two patients were the complaints spontaneous. A transient but significant rise in blood urea was observed in two patients in each treatment group, but in each case was attributable to reasons other than therapy. None of the other biochemical or haematological values tested deviated from normal.

Bacteriology.-The M.I.C. of ampicillin and cephalexin were determined for strains isolated from 42 patients (Table V). For only 4 out of 21 strains in the cephalexin group and 2 out of 21 strains in the ampicillin group was the M.I.C. of the respective antibiotic greater than $16 \mu \mathrm{g} / \mathrm{ml}$. However, only one patient, in the ampicillin-treated group, infected with

TABLE II-Results of Treatment

\begin{tabular}{|c|c|c|c|c|c|c|c|c|c|c|c|c|c|c|c|}
\hline \multirow{3}{*}{\multicolumn{2}{|c|}{ Drug }} & & \multirow{3}{*}{$\begin{array}{l}\text { No. of } \\
\text { Cases }\end{array}$} & \multicolumn{2}{|c|}{ At One Week } & \multicolumn{5}{|c|}{ At Three Weeks } & \multicolumn{5}{|c|}{ At Eight Weeks } \\
\hline & & & & \multirow{2}{*}{$\begin{array}{l}\text { Sterile } \\
\text { Urine }\end{array}$} & \multirow{2}{*}{$\begin{array}{l}\text { Infected } \\
\text { Urine }\end{array}$} & \multirow{2}{*}{$\begin{array}{l}\text { Sterile } \\
\text { Urine }\end{array}$} & \multicolumn{2}{|c|}{ Relapse } & \multirow[b]{2}{*}{ Defaulted } & \multirow[b]{2}{*}{ Died } & \multirow{2}{*}{$\begin{array}{l}\text { Sterile } \\
\text { Urine }\end{array}$} & \multicolumn{2}{|c|}{ Relapse } & \multirow[b]{2}{*}{ Defaulted } & \multirow[b]{2}{*}{ Died } \\
\hline & & & & & & & $\begin{array}{c}\text { Similar } \\
\text { Organism }\end{array}$ & $\begin{array}{l}\text { Different } \\
\text { Organism }\end{array}$ & & & & \begin{tabular}{|} 
Similar \\
Organism
\end{tabular} & $\begin{array}{l}\text { Different } \\
\text { Organism }\end{array}$ & & \\
\hline $\begin{array}{l}\text { Cephalexin .. } \\
\text { Ampicillin .. }\end{array}$ & .. & $\begin{array}{l}\ldots \\
\cdots\end{array}$ & $31 \stackrel{31}{(+2) *}$ & $\begin{array}{l}30 \\
28\end{array}$ & $\begin{array}{l}1 \\
3\end{array}$ & $\begin{array}{l}21 \\
20\end{array}$ & $\begin{array}{l}3 \\
4\end{array}$ & $\begin{array}{l}4 \\
3\end{array}$ & $\begin{array}{l}1 \\
1\end{array}$ & $\begin{array}{l}1 \\
0\end{array}$ & $\begin{array}{l}11 \\
11\end{array}$ & $\begin{array}{l}6 \\
1\end{array}$ & $\begin{array}{l}1 \\
3\end{array}$ & $\begin{array}{l}2 \\
3\end{array}$ & $\begin{array}{l}1 \\
2\end{array}$ \\
\hline
\end{tabular}

* Two patients stopped treatment prematurely because of diarrhoea.

TABLE III-Results of Treatment by Third Week Related to Infecting Organism

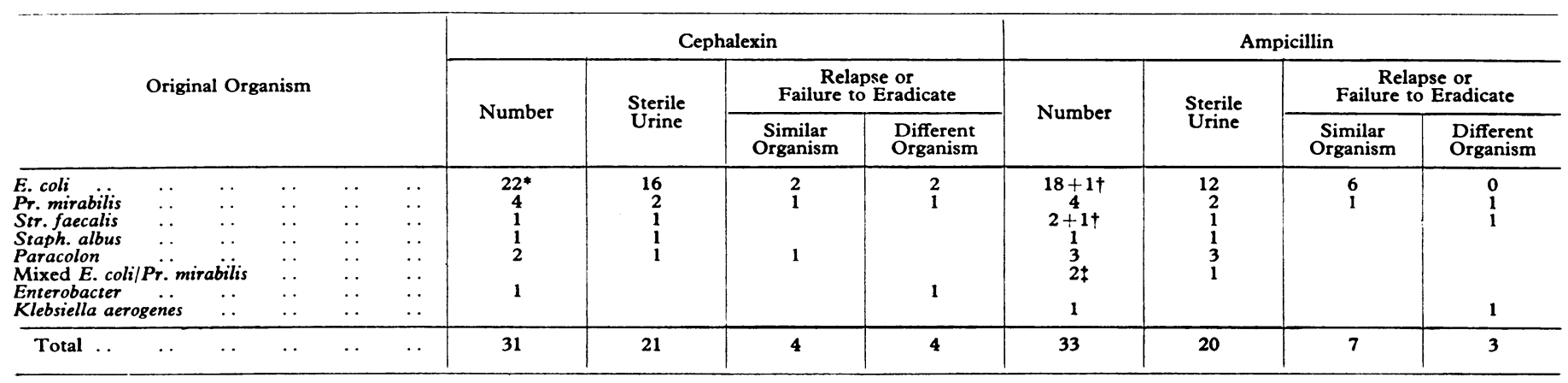

-Includes two patients, of whom one died and one defaulted.

+The two patients who stopped treatment prematurely.
tIncludes one patient who defaulted. 
an organism showing a high M.I.C. (and also resistant on preliminary testing) relapsed because of infection with an organism of similar strain.

TABLE v-Outcome Three Weeks after Start of Treatment Related to M.I.C. Determination

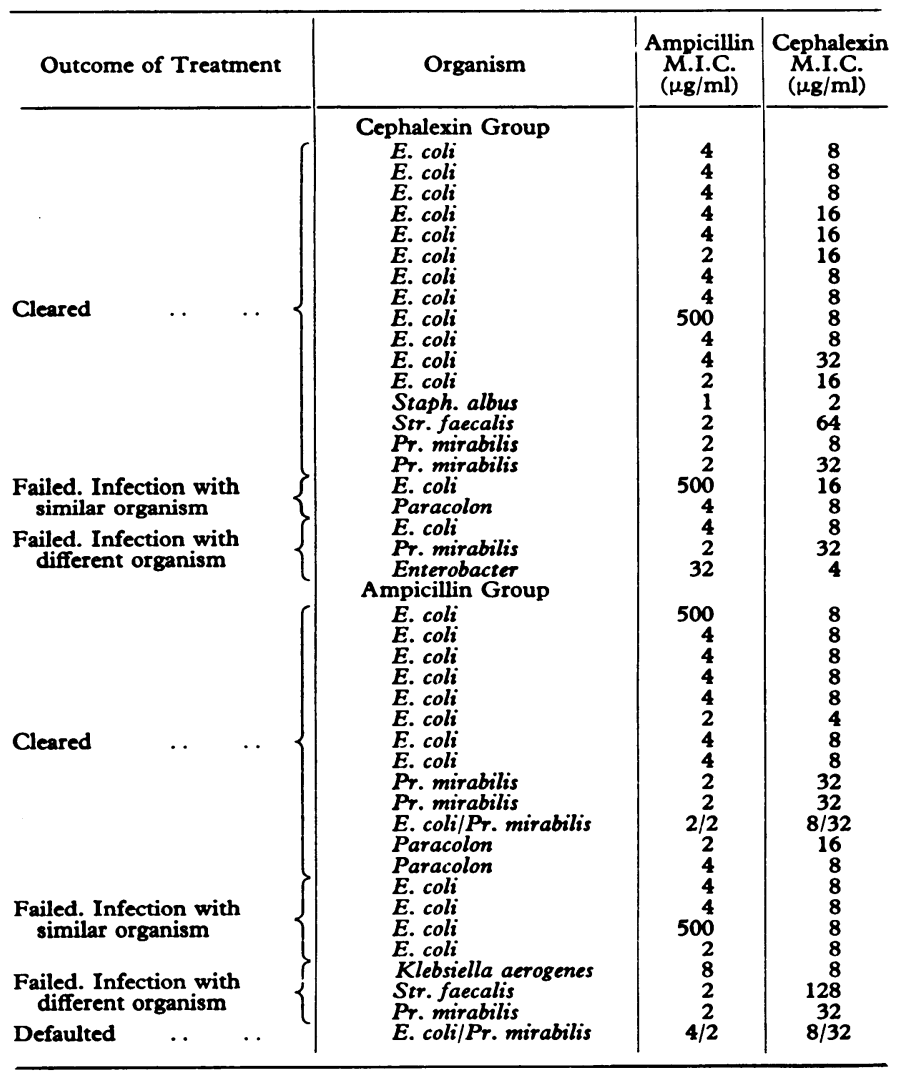

\section{Comment}

These results suggest that cephalexin and ampicillin are equally effective in the treatment of urinary infection. The proportion of patients relapsing because of infection with a similar organism to the original infecting strain compares favourably with that found in previous studies of similarly constituted groups of patients treated with cephalexin (Fairley, 1970) and ampicillin (Reeves, Faiers, Pursell, and Brumfitt,
1969). Treatment with either drug was particularly ineffective in the presence of complicating anatomical abnormalities of the urinary tract, and in none of the 10 patients with abnormalities on pyelography was the urine sterile by the eighth week.

Some reports have stressed a high incidence of adverse reactions and patient intolerance during treatment with cephalexin (Fairley, 1970; Leigh et al., 1970; Lancet, 1970), the principal symptoms being diarrhoea, nausea and vomiting, and vulvovaginitis. However, none of these studies was comparative. In the present study both the patients and the observer were aware that a new drug was under test, and this could have resulted in exaggeration of symptoms. However, on breaking the code, cephalexin seemed to have been tolerated slightly better than ampicillin. Only one patient in the cephalexin group was particularly troubled by diarrhoea, and this was not severe enough to cause him to curtail treatment. None of the patients complained of symptoms of vulvovaginitis and none was troubled by nausea or vomiting.

The study was supported in part by a grant from Glaxo Laboratories Ltd., who kindly provided the test capsules. We are grateful to Dr. J. Anderson, department of biomathematics, Oxford University, for advice during the design of the trial; to Mr. J. C. Smith, consultant surgeon, the Radcliffe Infirmary; and to Mr. W. Trilwood and Miss M. C. Craig, pharmacists, for administering the treatment schedule.

Reprint requests to Dr. J. M. Holt, Nuffield Department of Clinical Medicine, the Radcliffe Infirmary, Oxford OX2 6HE.

\section{References}

Anderson, K. N., Kennedy, R. P., Plorde, J. J., Shulman, J. A., and Petersdorf, R. G. (1964). Fournal of the American Medical Association, 187, 555.

Davies, J. A., Strangeways, J. E. M., and Holt, J. M. (1970). Postgraduate Medical fournal, 46, October Suppl., p. 16.

Fairley, K. F. (1970). Postgraduate Medical fournal, 46, October Suppl., p. 24.

Gower, P. E., and Dash, C. H. (1969). British fournal of Pharmacology, $37,738$.

Griffith, R. S., and Black, H. R. (1968). Clinical Medicine, 75, 14.

Guttman, D., and Stokes, E. J. (1963). British Medical fournal, 1, 1384.

Leigh, D. A., Faiers, M. C., and Brumfitt, W. (1970). Postgraduate Medical fournal, 46, October Suppl., p. 69.

Lancet, 1970, 2, 1296.

Meyers, B. R., Kaplan, K., and Weinstein, L. (1969). Clinical Pharmacology and Therapeutics, 10, 810 .

Perkins, R. L., Carlisle, H. N., and Saslaw, S. (1968). American fournal of Medical Science, 256, 122

Reeves, D. S., Faiers, M. C., Pursell, R. E., and Brumfitt, W. (1969). British Medical fournal, 1, 541.

Watt, P. R., Jefferies, L., and Price, S. A. (1966). Identification Methods for Microbiologists, Part A., ed. B. M. Gibbs and F. A. Skinner. London, Academic Press.

Wick, W. E. (1967). Applied Microbiology, 15, 765. 